\title{
ABTS Cation scavenging activity and total phenolic content of three moss species
}

\author{
Boris Pejin ${ }^{1,2}$, Jelena Bogdanović-Pristov ${ }^{1}$ \\ ${ }^{1}$ Department of Life Sciences, Institute for Multidisciplinary Research, University of Belgrade, Belgrade, Serbia \\ ${ }^{2}$ Department of Organic Chemistry, Faculty of Chemistry, University of Belgrade, Belgrade, Serbia
}

\begin{abstract}
A limited number of mosses have ever been studied in regard to antioxidant activity, with only a few belonging to the European species. As part of our ongoing screening of bryophytes as natural antioxidant resources, a relevant biological activity investigation was conducted on three moss species, namely Brachythecium rutabulum (Hedw.) Schimp. (Brachytheciaceae), Calliergonella cuspidata (Hedw.) Loeske (Hypnaceae) and Hypnum mammillatum (Brid.) Loeske (Hypnaceae), collected in Germany. The antioxidant activity of corresponding aqueous extracts was evaluated on the basis of their ABTS (2,2'-azino-bis(3-ethylbenzthiazoline-6-sulphonic acid)) cation scavenging activities. The total phenolic contents were determined as well. This study led to the detection of a moderate total phenolic content of the moss $B$. rutabulum, indicating for the first time its potential in searching for novel antioxidant agents.
\end{abstract}

Keywords: Brachythecium rutabulum; Calliergonella cuspidata; Hypnum mammillatum; antioxidant activity.

Available online at the Journal website: http://www.ache.org.rs/HI/

\section{RESEARCH NOTE}

UDC 582.322:66.094.8:547:615

Hem. Ind. 66 (5) 723-726 (2012)

doi: 10.2298/HEMIND120131022P
There is abundant evidence that oxidative stress imposed by reactive oxygen species plays an important role in many chronic and degenerative diseases, such as atherosclerosis, ischemic heart disease, cancer, diabetes mellitus, neurodegenerative diseases and ageing $[1,2]$. Dietary supplements of antioxidants have become popular to enhance the body's antioxidant defenses. Natural antioxidants may come from vegetables, fruits and beverages [3-7]. On the other hand, synthetic antioxidants are widely used in the food industry to protect food from oxidation and spoiling. However, some of synthetic antioxidants, such as butylated hydroxyanisole and butylated hydroxytoluene, have been found to be harmful for health due to their potential toxicity and carcinogenicity [8]. Therefore, there is an increasing interest for researchers in seeking for new resources of natural antioxidants, which are expected to be an alternative to synthetic ones $[9,10]$.

Bryophytes (mosses, liverworts and hornworts) are the third largest group of the land plants after flowering plants and ferns, with approximately 15000 species spread worldwide. This group of plants possesses a strong antioxidative machinery which helps to cope up with extreme climates and stresses. Heavy metal, desiccation and ultraviolet radiation have been found to activate an array of different enzymes in bryophytes [11]. The study of antioxidant activity of the Antarctic

Correspondence: B. Pejin, Department of Life Sciences, Institute for Multidisciplinary Research, Kneza Višeslava 1, 11030 Belgrade, Serbia.

E-mail: borispejin@imsi.rs; brspjn@gmail.com

Paper received: 31 January, 2012

Paper accepted: 5 March, 2012 mosses Sanionia uncinata (Hedw.) Loeske and Polytrichastrum alpinum (Hedw.) G.L. Sm. var. alpinum has indicated their potential to be used as a possible source of antioxidants for medicinal and cosmetic purpose $[12,13]$. Moreover, the antioxidant activity of Atrichum undulatum (Hedw.) P. Beauv., Polytrichum formosum Hedw., Pleurozium schreberi (Brid.) Mitt. and Thudium tamariscinium (Hedw.) Schimp. has been screened, and all tested species have showed antioxidant effects lower than the positive control, caffeic acid [14].

The objective of this study was to determine for the first time the antioxidant activity of aqueous extracts of three moss species, namely Brachythecium rutabulum, Calliergonella cuspidata and Hypnum mammillatum, in the context of their ABTS (2,2'-azino-bis(3-ethylbenzthiazoline-6-sulphonic acid)) cation scavenging activities and total phenolic contents.

\section{EXPERIMENTAL}

\section{Plant material}

All three samples of mosses were collected in Germany in December 2007: Calliergonella cuspidata (Hedw.) Loeske (Hypnaceae) and Hypnum mammillatum (Brid.) Loeske (Hypnaceae) in surrounding of Bonn and Brachythecium rutabulum (Hedw.) Schimp. (Brachytheciaceae) in Königsforst near Köln. Voucher specimens were deposited in the Herbarium of the Institute of Botany, University of Belgrade, Serbia (bryophyte collection - BEOU No. 4704, No. 4709 and No. 4707, respectively). 


\section{Extraction procedure}

The moss species were carefully selected and cleaned from soil and other contaminants. The gametophyte tips were used for the extractions. Air-dried parts of $B$. rutabulum ( $1 \mathrm{~g}), C$. cuspidata $(1 \mathrm{~g})$ and $H$. mammillatum $(1 \mathrm{~g})$ were ground and extracted with hot water $(3 \times 20$ $\mathrm{mL}$ ) for $30 \mathrm{~min}$. The extracts were filtered and concentrated by lyophilisation to give $0.11 \mathrm{~g}, 0.07$ and $0.05 \mathrm{~g}$ of the residue $(11,7$ and $5 \%$, extract yields respectively), which were stored at $4{ }^{\circ} \mathrm{C}$ for further use.

\section{Screening of antioxidant activity}

Determination of antioxidant activity was done following the ABTS method of Arnao et al. [15]. The reaction mixture contained $2 \mathrm{mM}$ ABTS (2,2'-azino-bis(ethylbenzothiazoline-6-sulfonic acid)), $15 \mu \mathrm{M}$ hydrogen peroxide and $0.25 \mu \mathrm{M}$ horse radish peroxidase (HRP) in $50 \mathrm{mM}$ phosphate buffer $\mathrm{pH}$ 7.5. The reactions were monitored at $730 \mathrm{~nm}$ (2501 PC Shimadzu, Kyoto, Japan) at $25{ }^{\circ} \mathrm{C}$ until a stable absorbance was obtained due to $A B T S$ radical formation. Afterwards, different concentrations $(0.05-0.80 \mathrm{mM})$ of ascorbic acid (AA) were added for a standard curve set-up. Addition of the extract in reaction mixture resulted in decrease in absorbance as a consequence of ABTS radical depletion. Absorbance alterations were read from standard curve and results were expressed as micrograms of $A A$ equivalent per milligram of the extract ( $\mu \mathrm{g} A \mathrm{~A} \mathrm{mg}^{-1}$ extract). The data are presented as mean \pm standard error of the three samples analysed separately.

The total phenolic content in the extracts was determined according to the Folin-Ciocalteu's spectrophotometric (2501 PC Shimadzu, Kyoto, Japan) procedure using ferulic acid (FA) as a standard for the calib- ration curve [16]. Samples were mixed with $0.25 \mathrm{~N}$ Folin-Ciocalteu reagents and after $3 \mathrm{~min} 0.2 \mathrm{M}$ sodium carbonate solution was added and incubated for 60 min. Results were read at $724 \mathrm{~nm}$ and expressed as micrograms of FA equivalent per milligram of the extract ( $\mu \mathrm{g} F \mathrm{Fg}^{-1}$ extract). The data are expressed as mean \pm standard error of the three samples analysed separately.

\section{RESULTS AND DISCUSSION}

The ABTS test showed the following data: $1 \mathrm{mg}$ of $B$. rutabulum extract was equivalent to $14.37 \pm 1.3 \mu \mathrm{g}$ of ascorbic acid (Figure 1); $1 \mathrm{mg}$ of $C$. cuspidata extract was equivalent to $6.47 \pm 1.12 \mu \mathrm{g}$ of ascorbic acid; $1 \mathrm{mg}$ of $H$. mammillatum extract was equivalent to $0.74 \pm 0.02$ $\mu \mathrm{g}$ of ascorbic acid. The total phenolic content in $1 \mathrm{mg}$ of $B$. rutabulum extract was equivalent to $110.47 \pm 5.11$ $\mu \mathrm{g}$ of ferulic acid as a standard (Figure 2); $1 \mathrm{mg}$ of $C$. cuspidata extract was equivalent to $50.06 \pm 2.96 \mu \mathrm{g}$ of ferulic acid; $1 \mathrm{mg}$ of $H$. mammillatum extract was equivalent to $48.11 \pm 2.73 \mu \mathrm{g}$ of ferulic acid.

Despite the majority previous studies $[17,18]$, aqueous extracts are analysed in this screening, as it has been the case in recent works [19-21]. In comparison with the other two examined mosses, $B$. rutabulum had the highest total phenolic content. Our results indicate the potential of its extract in searching for novel antioxidant agents, which could be useful from food functional and drug medicine aspects. Hence, in the future, the phenolic compounds from this moss extract should be isolated, identified and explored for their nutritional values and health effects in relation to oxidative stress.

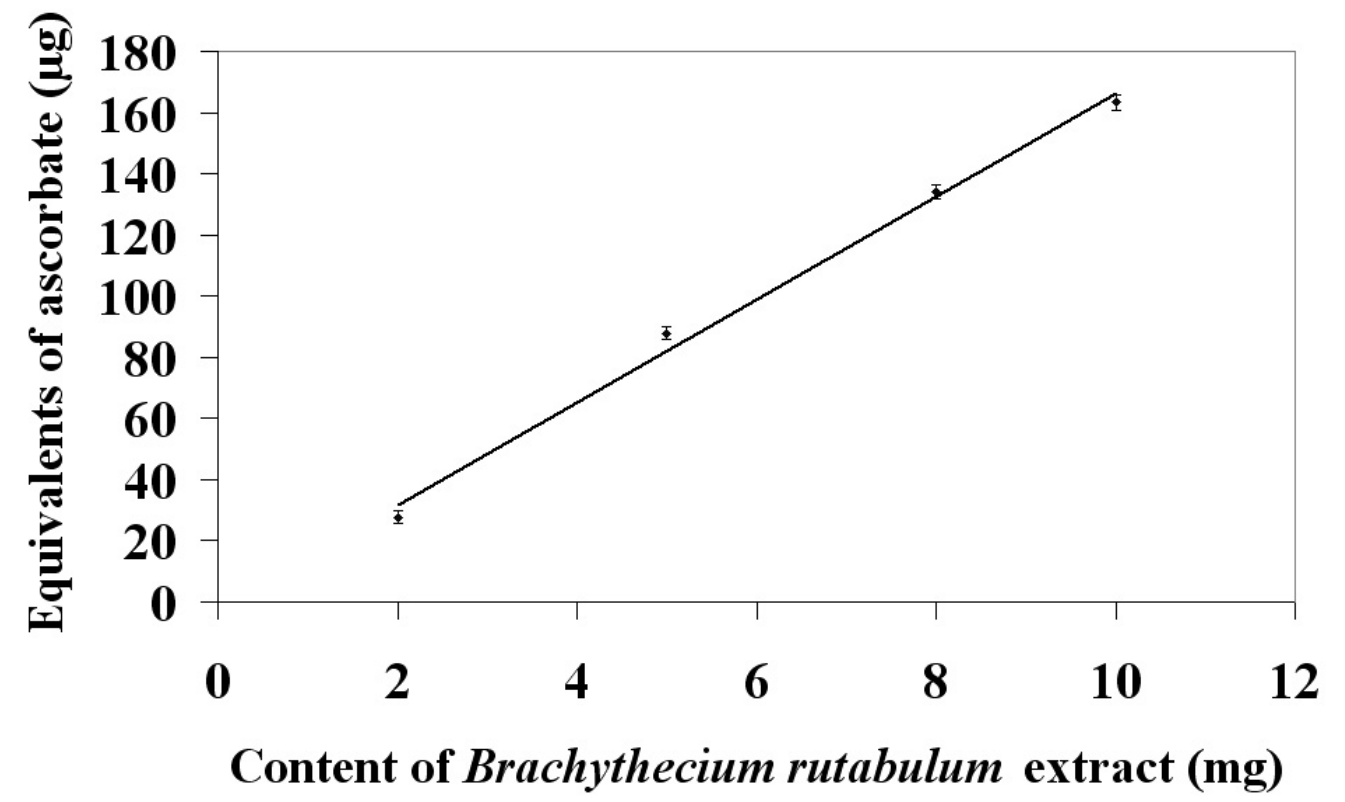

Figure 1. The ABTS cation scavenging activity of Brachythecium rutabulum. 


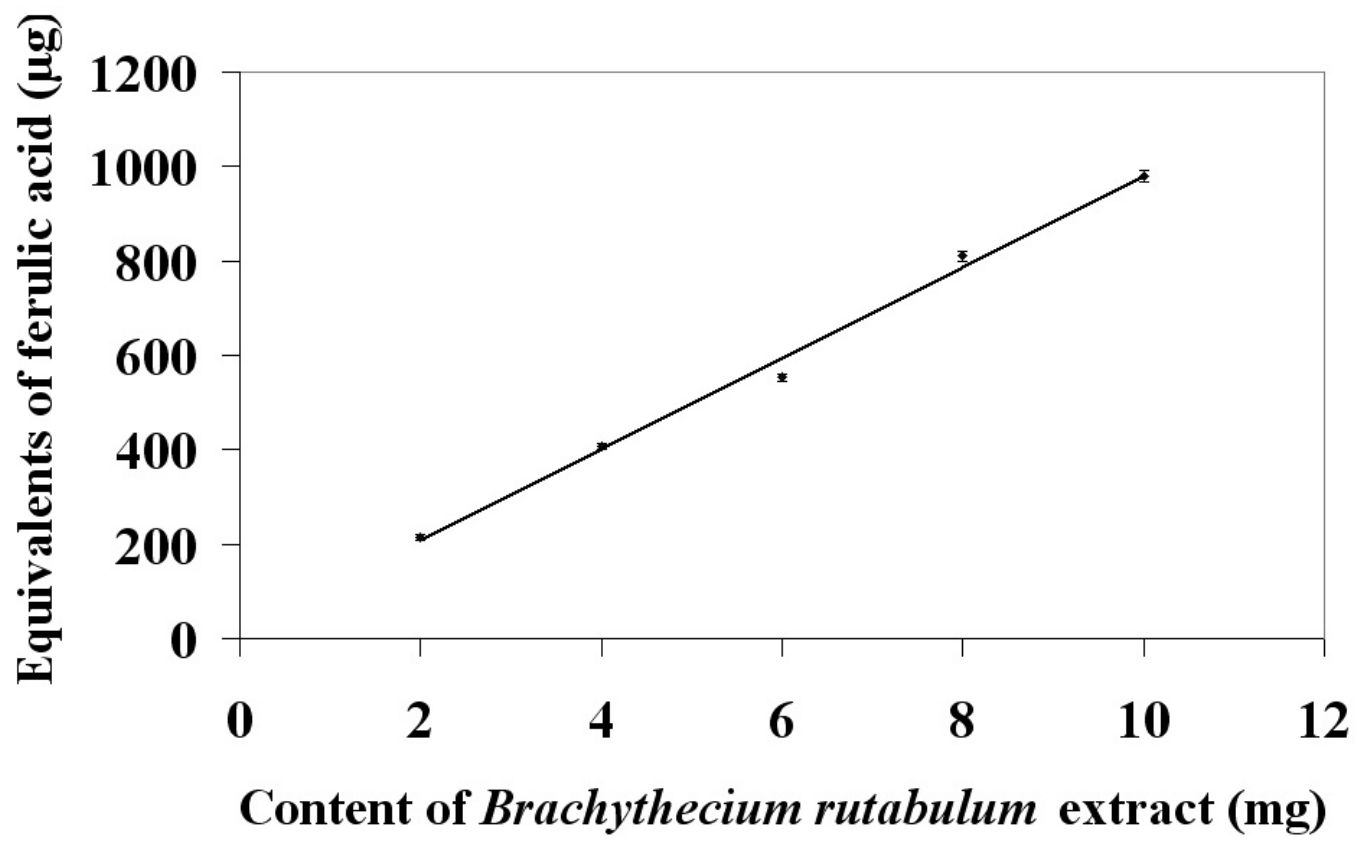

Figure 2. The total phenolic content of Brachythecium rutabulum.

\section{Acknowledgements}

This work was supported by the Ministry of Education, Science and Technological Development of the Republic of Serbia (Research grants Nos. 173017 and 173040). We gratefully acknowledge Dr. Marko Sabovljević (University of Belgrade, Serbia) for providing us biological samples.

\section{REFERENCES}

[1] I.S. Young, J.V. Woodside, Antioxidants in health and disease, J. Clin. Pathol. 54 (2001) 176-186.

[2] O.A. Azizova, Role of free radical processes in the development of atherosclerosis, Biol. Membr. 19 (2002) 451-471.

[3] M.V. Eberhardt, C.Y. Lee, R.H. Liu, Antioxidant activity of fresh apples, Nature 405 (2000) 903-904.

[4] H. Li, X.Y. Wang, Y. Li, P.H. Li, H. Wang, Polyphenolic compounds and antioxidant properties of selected China wines, Food Chem. 112 (2009) 454-460.

[5] A.M. Pisoschi, M.C. Cheregi, A.F. Danet, Total antioxidant capacity of some commercial fruit juices: electrochemical and spectrophotometrical approaches, Molecules 14 (2009) 480-493.

[6] T. Stangeland, S.F. Remberg, K.A. Lye, Total antioxidant activity in 35 Ugandan fruits and vegetables, Food Chem. 113 (2009) 85-91.

[7] M.N. Mitic, M.V. Obradovic, Z.B. Grahovac, A.N. Pavlovic, Antioxidant capacities and phenolic levels of different varietes of Serbian white wines, Molecules 15 (2010) 2016-2027.

[8] A.A.M. Botterweck, H. Verhagen, R.A. Goldbohm, J. Kleinjans, P.A. Van Den Brandt, Intake of butylated hydroxyanisole and butylated hydroxytoluene and stomach cancer risk: results from analyses in the Netherlands cohort study, Food Chem. Toxicol. 38 (2000) 599-605.

[9] A Trichopoulou, T. Costacou, C. Bamia, D. Trichopoulos, Adherence to a Mediterranean diet and survival in a Greek population, New Engl. J. Med. 348 (2003) 2599-2608 .

[10] B.C. Behera, N. Verma, A. Sonone, U. Makhija, Determination of antioxidative potential of lichen Usnea gattensis in vitro, Lebenson Wiss Technol. 39 (2006) 80-85.

[11] A. Dey, J.N. De, Antioxidative potential of bryophytes: stress tolerance and commercial perspectives: a review, Pharmacologia 3 (2012) 151-159.

[12] H.D. Bhattarai, B. Paudel, H.S. Lee, Y.K. Lee, J. Yim, Antioxidant activity of Sanionia uncinata, a polar moss species from King George Island, Antarctica, Phytother. Res. 22 (2008) 1635-1639.

[13] H.D. Bhattarai, B. Paudel, H.K. Lee, H. Oh, J.H. Yim, In vitro antioxidant capacities of two benzonaphtoxanthenones: Ohiensis $F$ and $G$, isolated from the Antarctic moss Polytrichastrum alpinum, Z. Naturforsch. C. 64 (2009) 197-200.

[14] V. Chobot, L. Kubicová, S. Nabbout, L. Jahodář, F. Hadacek, Evaluation of antioxidant activity of some common moss species, Z. Naturforsch. C. 63 (2008) 476-482.

[15] M.B. Arnao, A. Cano, M. Acosta, Methods to measure the antioxidant activity in plant material. A comparative discussion, Free Radical Res. 32 (1999) 89-96.

[16] V.L. Singleton, J.A. Rossi, Colorimetry of total phenolics with phosphomolybdic phosphotungstic acid reagents, Am. J. of Enol. Viticult. 16 (1965) 144-158.

[17] S. Sorbo, A. Basile, R.C. Cobianchi, Antibacterial, antioxidant and allelopathic activities in bryophytes, Resent Res. Dev. Phytochem. 8 (2004) 69-82. 
[18] V. Chobot, L. Kubicová, S. Nabbout, L. Jahodář, J. Vytlačilová, Antioxidant and free radical scavenging activities of five moss species, Fitoterapia 77 (2006) 598-600.

[19] A.A. Ivanov, N.V. Yudina, E.I. Korotkova, O.I. Lomovsky, Antioxidants in the water-soluble carbohydrate fractions of the moss Sphagnum fuscum and sphagnum peat, Solid Fuel Chem. 42 (2008) 68-73.
[20] B. Pejin, J. Bogdanovic-Pristov, I. Pejin, M. Sabovljevic, Potential antioxidant activity of the moss Bryum moravicum, Nat. Prod. Res. (2013), in press, DOI: 10.1080/ /14786419.2012.665915.

[21] B. Pejin, Y. Kien-Thai, J. Bogdanovic-Pristov, I. Pejin, I. Sabovljevic, In vitro investigation of the antihypertensive effect of the moss Rhodobryum ontariense (Kindb.) Kindb., Dig. J. Nanomater. Bios. 7 (2012) 353-359.

\section{IZVOD}

\section{SPOSOBNOST NEUTRALIZACIJE ABTS RADIKAL-KATJONA I SADRŽAJ UKUPNIH FENOLA TRI VRSTE MAHOVINE}

\section{Boris Pejin ${ }^{1,2}$, Jelena Bogdanović-Pristov ${ }^{1}$}

${ }^{1}$ Odsek za nauke o živim sistemima, Institut za multidisciplinarna istraživanja, Univerzitet u Beogradu, Kneza Višeslava 1, Beograd, Srbija

${ }^{2}$ Katedra za organsku hemiju, Hemijski fakultet, Univerzitet u Beogradu, Studentski trg 16, Beograd, Srbija

(Kratko saopštenje)

Do sada je veoma malo proučavana antioksidativna aktivnost mahovina sa evropskog tla. Stoga je u ovom radu in vitro ispitivana sposobnost neutralizacije ABTS radikal katjona (2,2'-azinobis(3-etilbenzotiazolin-6-sulfonske kiseline)) i sadržaj ukupnih fenola vodenih ekstrakata tri vrste mahovine (Brachythecium rutabulum (Hedw.) Schimp. (Brachytheciaceae), Calliergonella cuspidata (Hedw.) Loeske (Hypnaceae) i Hypnum mammillatum (Brid.) Loeske (Hypnaceae)) sakupljene u Nemačkoj za vreme zimskog doba. Dobijeni rezultati ukazuju na to da ekstakt $B$. rutabulum može potencijalno da se smatra dobrim izvorom novih prirodnih supstanci sa antioksidativnom aktivnošću.

Ključne reči: Brachythecium rutabulum • Calliergonella cuspidata $\bullet$ Hypnum mammillatum • Antioksidativna aktivnost 